\title{
Rancang Bangun Sistem Pemantauan Kinerja Panel Surya Tipe Mono- Crystalline Silicon Berbasis IoT
}

\author{
Mahardika Yoga Darmawan ${ }^{1}$, Mohamad Samsul Anrokhi ${ }^{2}$, Ali Komarudin ${ }^{3}$ \\ Program Studi Fisika, Institut Teknologi Sumatera, Lampung Selatan \\ Jalan Terusan Ryacudu, Way Hui, Kecamatan Jati Agung, Lampung Selatan 35365 \\ ${ }^{1}$ mahardika.yogaefi.itera.ac.id \\ 2 anrokhiefi.itera.ac.id \\ 3 alikomarudin07@gmail.com
}

\begin{abstract}
Abstrak - Panel surya dapat diketahui kinerjanya dengan cara mengukur parameter arus dan tegangan namun untuk mendapatkan informasi yang akurat dan berkelanjutan maka perlu adanya sistem pemantuan terhadap panel surya tersebut. Sistem pemantauan pada penelitian ini dibuat dengan berbasis ATMEGA328P, ESP 8266, sensor arus dan tegangan. Dapat disimpulkan bahwa untuk sistem pemantuan kinerja panel surya dalam pengujian memiliki galat sebesar $0.2 \%$ untuk sensor tegangan, $0.17 \%$ untuk sensor arus. Untuk data dari sistem pemantuan menunjukkan nilai rata-rata tegangan dan arus sebesar 20.75 volt dan 2.81 ampere dengan standar deviasi 0.32 volt dan 0.14 ampere serta 15 detik untuk jeda pengiriman data ke platform penyimpan data.
\end{abstract}

Kata kunci —Panel Surya, Arus, Tegangan, Pemantauan.

Abstract - Solar panels can be accessed by measuring the current and voltage parameters to obtain accurate and necessary information, so a system of monitoring for the solar panels is needed. The improvement system in this study was made based on ATMEGA328P, ESP 8266, current and voltage sensors. It can be concluded that the solar panel monitoring system in the test has an error of $0.2 \%$ for voltage sensor, $0.17 \%$ for current sensor. Data from the monitoring system, the average voltage and current values are 20.75 volts and 2.81 amperes with a standard deviation of 0.32 volts and 0.14 ampere then it takes 15 seconds for time delay in sending data to a data storage platform.

Keywords - Solar Panels, Current, Voltage, Monitoring .

\section{PENDAHULUAN}

Kebutuhan energi listrik tiap tahun semakin besar, namun penyediaan untuk sumber energi listrik semakin terbatas. Sumber energi listrik saat ini berasal dari sumber energi fosil yang tidak bisa diperbarui sehingga diperlukan sumber energi alternatif seperti energi matahari dengan memanfaatkan panel surya. Kinerja panel surya secara umum dapat dilihat dari arus dan tegangan yang diakibatkan oleh radiasi matahari. Pengukuran arus dan tegangan secara langsung secara umum menggunakan multimeter. Pada penelitian sebelumnya [1] telah dilakukan penelitian yaitu pengamatan pengambilan data dan pengukuran pada panel surya namun dalam penelitian tersebut terdapat kekurangan karena data yang didapatkan tidak diperoleh secara real time dan berkelanjutan untuk disimpan dalam sebuah data logger.
Dengan permasalahan diatas, beberapa penelitian telah dilakukan seperti pemantauan parameter panel dengan akuisisi data pengukuran yang terintegrasi dengan spreadsheet excel [2] dan pembuatan sistem monitoring energi listrik dengan menggunakan nodemcu[3]. Pada penelitian ini dikembangkan sebuah alat sederhana yang dapat digunakan untuk mengukur dan menyimpan data arus dan tegangan secara real time dan berkelanjutan.

\section{METODE PENELITIAN}

Rancang bangun sistem pemantauan kinerja panel surya pada penelitian ini dibuat dengan menggunakan atmega328, esp 8266, sensor arus dan tegangan ina219 serta platform ThinkSpeak digunakan penyimpanan data berfungsi sebagai pengumpul dan penyimpan data kinerja panel surya.

Platform ThinkSpeak berbasis open source dan sudah terintegrasi dengan matlab. 
Diagram skematik dari alat dapat dilihat pada gambar 1.

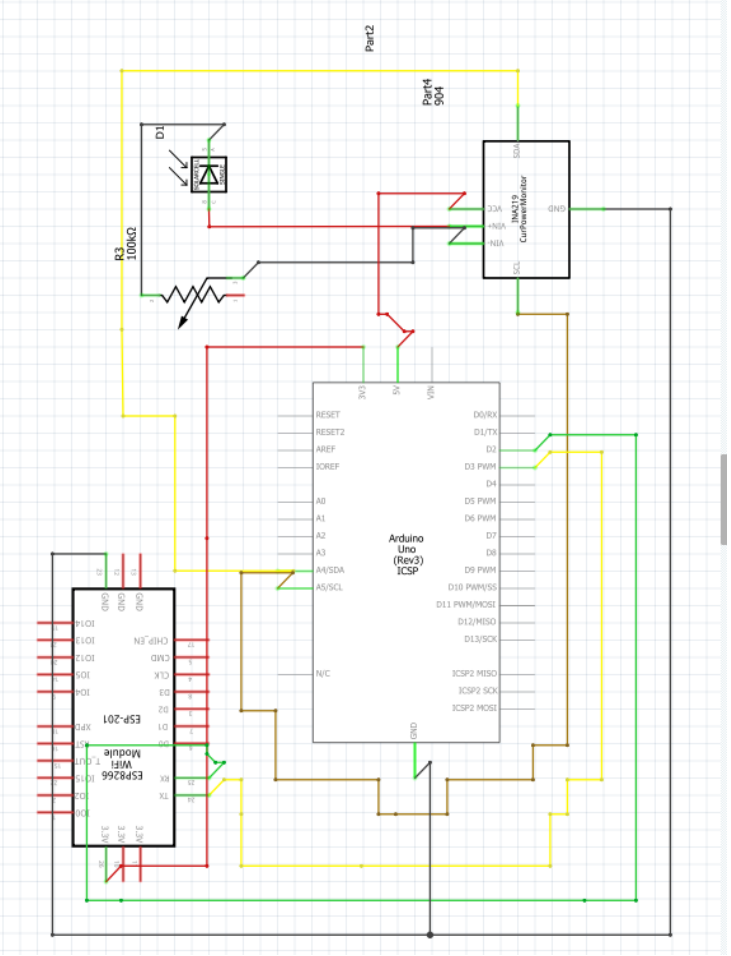

Gbr.1 Diagram skematik alat pemantauan kinerja panel surya

Panel surya yang digunakan pada penelitian ini berjenis monokristal. Spesifikasi lengkap dari panel surya dapat dilihat pada tabel 1 .

Tabel 1. Spesifikasi Panel Surya

\begin{tabular}{|c|c|}
\hline Spesifikasi & Keterangan \\
\hline $\begin{array}{c}\text { Max. Power (Pmax) } \\
\text { (Vower Voltage }\end{array}$ & $100 \mathrm{~W}$ \\
\hline $\begin{array}{c}\text { Max. Power Current } \\
\text { (Imp) }\end{array}$ & $18 \mathrm{~V}$ \\
\hline $\begin{array}{c}\text { Open Circuit Voltage } \\
\text { (Voc) }\end{array}$ & $21.6 \mathrm{~V}$ \\
\hline $\begin{array}{c}\text { Short Circuit Current } \\
\text { (Isc) }\end{array}$ & $6.12 \mathrm{~A}$ \\
\hline Tolerance & $\pm 3 \%$ \\
\hline $\begin{array}{c}\text { Max. System } \\
\text { Operating Voltage }\end{array}$ & $1000 \mathrm{VDC}$ \\
\hline Protection Class & Class A \\
\hline Cell Technology & $7 \mathrm{Kg}$ \\
\hline Weight & $1196 \times 541 \times 30 \mathrm{~mm}$ \\
\hline Dimension
\end{tabular}

Pengujian sistem pemantauan kinerja panel surya dilakukan secara langsung tanpa melalui controller sehingga dibutuhkan beban berupa resistor balok dengan nilai hambatan 10 kiloOhm berdaya $1 \mathrm{~W}$ pada penelitian ini.

Keseluruhan diagram alir penelitian dapat dilihat pada gambar 2 .

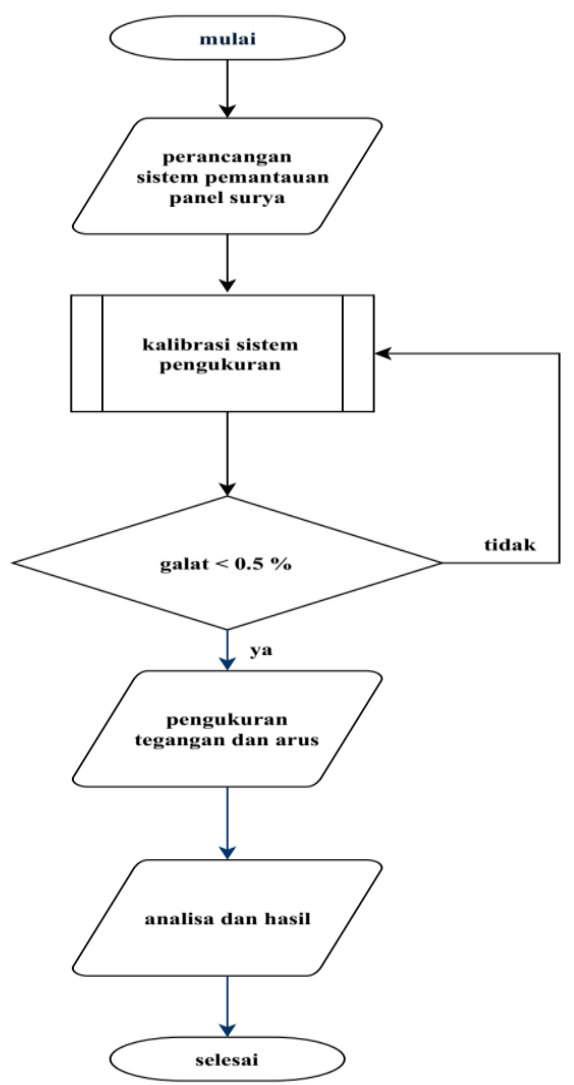

Gbr. 2 Diagram alur penelitian

Pada penelitian ini digunakan sensor ina219 sebagai sensor untuk mengukur arus dan tegangan. Spesifikasi dari sensor ina219 dapat digunakan untuk mengukur tegangan dari 0 sampai 26 volts.[4] Untuk pengujian sensor arus dan tegangan dilakukan dengan membandingkan sumber arus dan tegangan DC GW Instek GPS-3030D dan multimeter SANWA CD 771. Hasil kalibrasi dapat dilihat pada tabel 1.

Tabel 2. Hasil Uji Sensor Arus dan Tegangan dengan Multimeter

\begin{tabular}{|c|c|c|c|c|}
\hline $\begin{array}{l}\text { Power } \\
\text { Supply }\end{array}$ & Multimeter & $\begin{array}{c}\text { Sensor } \\
\text { Arus }\end{array}$ & $\begin{array}{c}\text { Sensor } \\
\text { Tegangan }\end{array}$ & Galat \\
\hline $3 \mathrm{~V}$ & $3 \mathrm{~V}$ & - & $3.00 \mathrm{~V}$ & $0 \%$ \\
\hline $5 \mathrm{~V}$ & $5 \mathrm{~V}$ & - & $5.02 \mathrm{~V}$ & $0.4 \%$ \\
\hline \multicolumn{4}{|c|}{ Rata-Rata } & $0.2 \%$ \\
\hline $2 \mathrm{~A}$ & $2 \mathrm{~A}$ & $2.00 \mathrm{~A}$ & - & $0 \%$ \\
\hline $3 \mathrm{~A}$ & $3 \mathrm{~A}$ & $3.01 \mathrm{~A}$ & - & $0.33 \%$ \\
\hline \multicolumn{4}{|c|}{ Rata-Rata } & $0.17 \%$ \\
\hline
\end{tabular}


Berdasarkan pengujian sensor terhadap power supply dan multimeter menunjukkan galat yang ditunjukkan sensor pada tabel 1 masih berada dibawah $0.5 \%$ untuk pembacaan arus dan tegangan dengan menggunakan sensor ina219.

\section{HASIL DAN PEMBAHASAN}

Data arus dan tegangan diperoleh dari alat pemantauan yang dipasang pada panel surya dengan pengukuran dan penyimpanan datanya dimulai pukul 00.00 - 23.59 WIB selama 5 hari dan berlokasi di ITERA. Data tersimpan dalam platform Think Speak berupa format .txt kemudian diolah dan dianalisis.

Pada gambar 3 terlihat bahwa pada pukul 04.30 dini hari untuk nilai tegangan dan arus yang didapatkan mulai mengalami peningkatan sedangkan pada pukul 15.30 mulai mengalami penurunan. Nilai rata-rata tegangan pada panel surya dari pukul 05.30 sampai pukul 15.00 bernilai 20.75 volt dan arus bernilai 2.81 ampere serta dari data tersebut memperlihatkan kestabilan dari nilai pengukuran panel surya dengan standar deviasi pengukuran 0.32 volt dan 0.14 ampere. Untuk total data harian Hasil penelitian ini memiliki nilai dan kemiripan karakteristik panel surya yang didapatkan pada penelitian sebelumnya.[5]

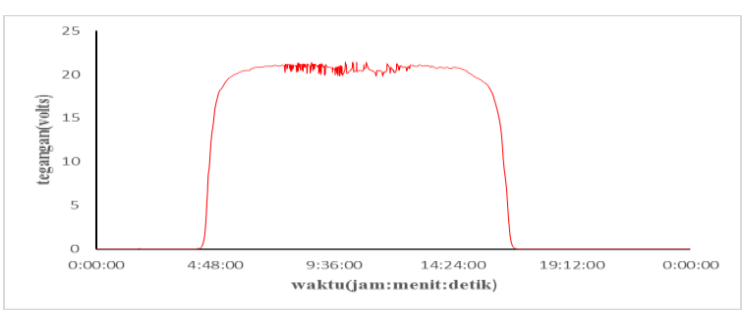

(a)

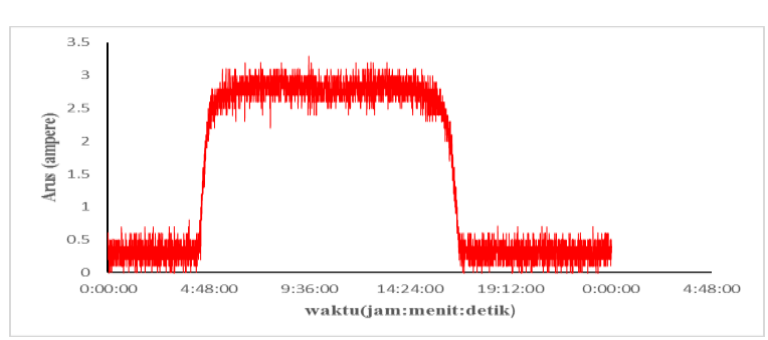

(b)

Gbr.3 (a). Grafik tegangan terhadap waktu, (b). Grafik arus listrik terhadap waktu

\section{KESIMPULAN}

Pengambilan data diambil dengan menggunakan alat ini dapat digunakan untuk mengukur dan merekam data secara real time ke ThinkSpeak. Data dari ThinkSpeak dapat disimpan dalam bentuk format .txt dan memudahkan dalam pengolahan dan analisis data. Alat yang ditunjukkan mampu menunjukkan hasil yang valid dengan membandingkan dengan penelitian sebelumnya.

\section{UCAPAN TERIMA KASIH}

Terima kasih kepada Institut Teknologi Sumatera atas bantuan dana penelitian ini melalui Program Hibah Mandiri.

\section{REFERENSI}

[1] Y. D. Arfita and Antonov, "Pemanfaatan energi surya sebagai suplai cadangan pada laboratorium elektro dasar di institut teknologi padang," J. Tek. Elektro, vol. 2, no. 3, pp. 20-28, 2013.

[2] M. R. Fachri, I. D. Sara, and Y. Away, "Pemantauan Parameter Panel Surya Berbasis Arduino secara Real Time," $J$. Rekayasa Elektr., vol. 11, no. 4, p. 123, 2015.

[3] C. Paper, W. Winasis, U. Jenderal, A. Wisnu, W. Nugraha, and U. Jenderal, "Perancangan Sistem Monitoring Energi Listrik Panel Surya Berbasis IOT," no. March, 2017.

[4] T. Instrument, "CURRENT SENSORS[Material Safety Data Sheet]," no. August, 2008.

[5] K. Kananda, "Studi Awal Potensi Energi Surya Wilayah Lampung: Studi Kasus Kampus Institut Teknologi Sumatera (ITERA) Menuju Smart Campus," J. Sci. Appl. Technol., vol. 1, no. 2, pp. 75-81, 2017. 